\title{
Home Point Study of Birds and Mammals Diversity Allied to Humans in Lockdown of COVID-19 at Bharatpur, Chitwan, Nepal
}

\author{
Budhan Chaudhary \\ Birendra Multiple Campus, Tribhuvan University, Bharatpur, Chitwan, Nepal \\ Email: chaudharybudhan@gmail.com
}

How to cite this paper: Chaudhary, B. (2020) Home Point Study of Birds and Mammals Diversity Allied to Humans in Lockdown of COVID-19 at Bharatpur, Chitwan, Nepal. Open Journal of Ecology, 10, 612-631.

https://doi.org/10.4236/oje.2020.109038

Received: August 10, 2020

Accepted: September 22, 2020

Published: September 25, 2020

Copyright $\odot 2020$ by author(s) and Scientific Research Publishing Inc. This work is licensed under the Creative Commons Attribution International License (CC BY 4.0).

http://creativecommons.org/licenses/by/4.0/

\begin{abstract}
The birds and mammals are nature gifted gene banks which differ greatly with variation in altitudes, climates, landscapes, vegetation and availability of food and water. The altitudinal variation in Nepal is $60 \mathrm{~m}$ to $8,848 \mathrm{~m}$ which affects climatic conditions and habitat types within short distance that influence species diversity of wild animals. Therefore, the objectives of this study were to reveal species richness, behaviors and luring factors for birds and mammals to attract to an urban area of Bharatpur Metropolitan City, the South-central lowland of Nepal. The methods applied to record species diversity of birds and mammals were made from a home point (a point of study made at the North-west corner of verandah in first floor of my home) located in Bharatpur-9, Saradpur, Sitalpath, in the coordinates of $27^{\circ} 39^{\prime} 55^{\prime \prime} \mathrm{N}$ and $84^{\circ} 26^{\prime} 08^{\prime \prime E}$. The animal species were observed thrice daily (at $7 \mathrm{AM}, 10 \mathrm{AM}$ and $2 \mathrm{PM}$ ) for 2 months beginning from 24 March to 23 May 2020 during the period of lockdown of COVID-19 and were listed in "Observation Data Sheet". The photographs and/or videos were taken except one of the species of bats (i.e. Myotis formosus) and six species of birds which were flying swiftly over the sky in $70 \mathrm{~m}$ in diameter (i.e. 7,436 square meters or $22 \mathrm{kattha}$ in area) of the home point. The results obtained from my study were; 83 species, 53 genera and 37 families of wild birds; and 6 species, 5 genera and 3 families of wild mammals. Among birds, Dicrurus and Ploceus were recorded the highest 7.54\% (4/53); followed by Acridotheres, Megalaima, Merops, Oriolus, Psittacula and Streptopelia with 5.66\% (3/53), and remaining twelve genera were found $3.77 \%(2 / 53)$, and thirty three genera were $1.88 \%(1 / 53)$. Similarly, 33.33\% (2/6) of Herpestes, and 16.66\% (1/6) of each Canis, Vulpes, Pipistrellus and Myotis were recorded among mammals. Conclusively, I found that the species of birds and mammals were lured to human settlement area due to availability of food (i.e. small in/vertebrates, kitchen garbage etc.);
\end{abstract}


crops (i.e. maize, sesame etc.); vegetables (i.e. bean); fruits (litchi, mango, berries etc.); nesting places and healthy environment. However, there is great chance of transmission of viral (rabies, foot-mouth disease etc.), bacterial (tuberculosis) and parasitic zoonoses (echinococcosis, toxoplasmosis, helminthiasis etc.) to humans and domesticated animals through feces and saliva droppings in addition to the poultry raiding, biting to people and damage of fruits, vegetables and crops creating conflicts.

\section{Keywords}

Conflicts, COVID-19, Garbage, Predators, Zoonotic Diseases

\section{Introduction}

The birds and mammals are natural gene pools which differ greatly with variation in topography, and the environmental factors like altitudes, landscapes, climates, vegetation, availability of food and water, etc. The altitudinal variation in Nepal is $60 \mathrm{~m}$ to $8,848 \mathrm{~m}$ which affects climatic conditions and habitat types within short distance that influence species diversity of wild birds [1] [2] and wild mammals [3]. The temperature ranges from 7 degree Celsius in winter (January) to 34 degree Celsius in summer (May) in Bharatpur with annual rain fall 1,993 $\mathrm{mm}$ in average [4] which affects in growth of plants [5] and crop production [6] increasing insect population [7] [8] as well as livestock infestation [9] that influence microhabitat or local ecosystem [10]. The temperature and human density also affect population of mollusks like giant African snail (Achatina fulica) [11] which is one of the prime food of greater coucal bird (Centropus sinensis).

There are 18,043 living wild bird species [12] and 6,495 living wild mammal species [13] in the world. Nepal carries $4.91 \%(n=886)$ of the bird species [14] and $3.46 \%(n=225)$ of the mammals species of the world [15]. Total 543 species of birds and 68 species of mammals were reported from Chitwan National Park (CNP) and adjoining community forests of buffer zone areas [16]. In addition to these, 244 species of birds and 28 species of mammals were recorded from urban area (ex-situ habitat) of Bharatpur Metropolitan City (BMC) [17] [18]. The fragmented greenery, gardens, bushes and agricultural crops are important to attract wildlife to urban areas [7] [19] [20].

Several researches were accomplished to reveal species diversity and wildlife conflicts [21] [22] in Protected Areas (PAs) like National Parks and buffer zones of Terai. The PAs occupy 17.32\% (1.03 million hectares) of the total forests whereas $82.68 \%$ (4.93 million hectares) are outside of Protected Areas [23]. Altogether, 27 Important Bird Areas (IBAs) were reported including forests, grasslands and fresh water ecosystems [24]. However, the IBAs from urban localities are yet to declare. The studies performed in PAs are mainly concerned with species diversity with little information to disclose behaviors and conflicts of wild 
mammals with people [22] [25] [26].

The premier study was carried out to enlist diversity of urban birds and mammals from ex-situ habitat of Bharatpur Metropolitan City [17] [18]. Yet, there is need of behavior research of wild birds and mammals associated with human population and interacting one or other way to adapt in highly populated area in spite of dreadful threats created by conflicts. Therefore, in-depth study of animal population influenced by microclimates [27] of an urban area in BMC can open fields for new researchers to learn their adaptive behaviors, abundance, public importance (economy and diseases) and conflicts with human in microhabitat.

\section{Significances of the Study}

This study has great importance mainly in two ways. The first and the most precious importance is: Reveal of species diversity of wild birds and mammals and their behaviors such as indicators of environment (i.e. commencement of pre-monsoon and monsoon, free of pesticides and other pollutions etc.), fixing of territory, feeding, courtship and nesting, parental care, aggression and defense, inter and/or intra-species interactions, and conflicts posed by socio-economic (plant pollination, crop damage, disease in domestic animals etc.) and/or socio-health problems (animal bite, transfer of zoonotic diseases etc.) in human population of the urban ecosystem. Secondly: The study discloses the increased behavior of wild animals in human settlement area in absence of vigorous human activities at the period of lock down of COVID-19.

\section{Materials and Methods}

\subsection{Materials}

The normal camera-Nikon COOLPIX S6400 (with 12X zoom) was used to take photographs or videos or both of the birds and mammals. The "Observation Data Sheets" were used to list the species diversity and behaviors. The pen and pencils were used to write on data sheet and erasers were used to erase when needed.

\subsection{Methods}

\subsubsection{Study Site}

The study area is located in about 250 meters $(\mathrm{m})$ of air distance from the Bharatpur Central Bus Park in Bharatpur Metropolitan City at ward number-9 (Saradpur, Sitalpath), Chitwan, Nepal and comprised around $70 \mathrm{~m}$ in diameter and 7,436 square meters (i.e. 22 kattha) in area from "a home point" (a point of study made in a corner of verandah of first floor of my house) located in the coordinates of $27^{\circ} 39^{\prime} 55^{\prime \prime} \mathrm{N}$ and $84^{\circ} 26^{\prime} 08^{\prime \prime} \mathrm{E}$ and $194 \mathrm{~m}$ above sea level (a.s.l.). The diameter was taken in three directions (i.e. North, East and West) from the home point because the South direction was blocked by wall of the house (Figure 1).

Bharatpur Metropolitan City consists of 29 wards with 433 square kilometers that represents $19.34 \%$ area of Chitwan District (i.e. 2,238.39 kilometers) and 


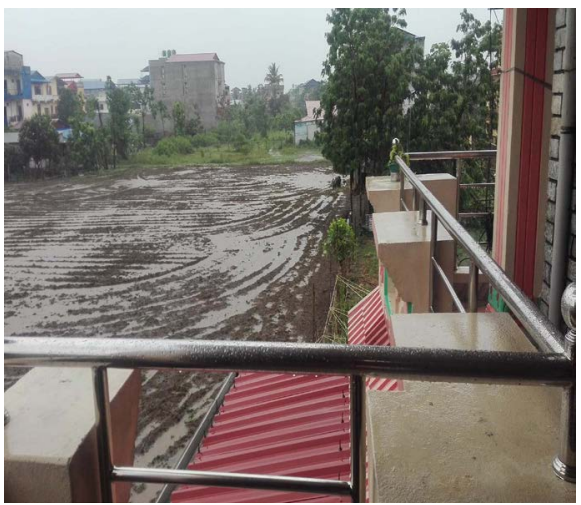

(a)

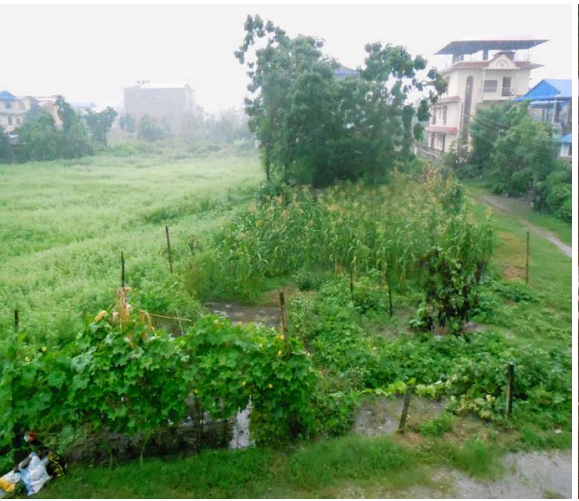

(c)

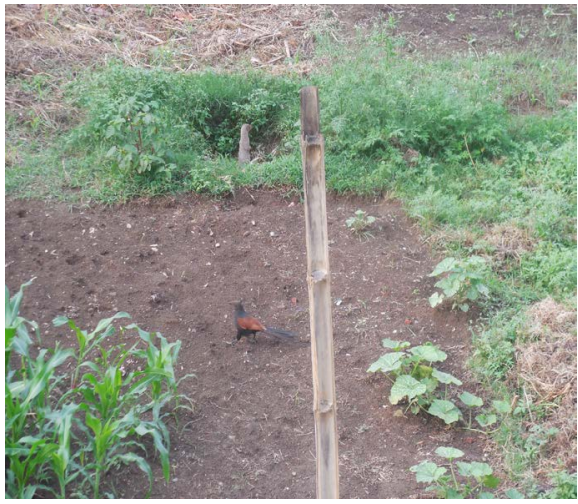

(e)

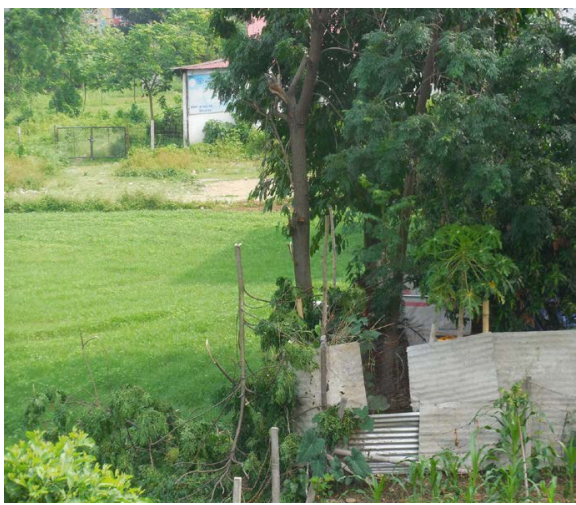

(b)

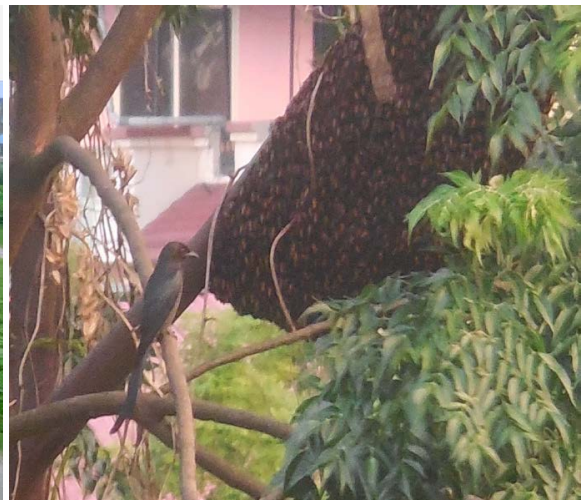

(d)

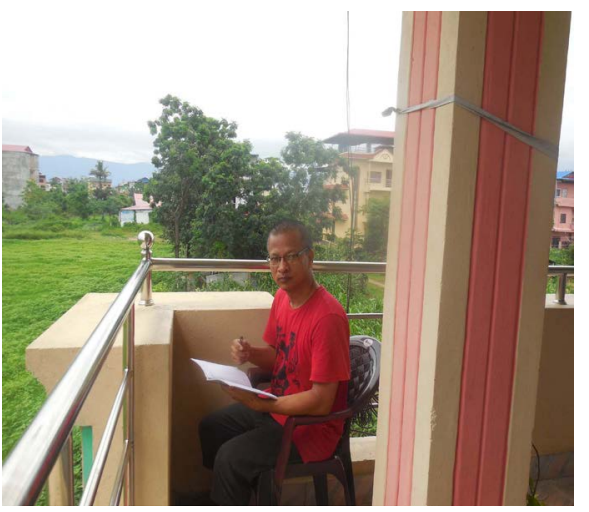

(f)

Figure 1. Micro-ecosystem with rapid changes: Plowed field seen after rain (a), Chinese Berry with cut branch (b), grown crops and vegetables (c), Ashy Drongo infront of resting bee (d), kitchen garbage eating Small Asian Mongoose and Greater Coucal in cleared field (e), and the researcher sitting at "a home point" to record data in "Observation Data Sheet" (f).

locates in the South-central lowland area of Nepal in the coordinates of $27^{\circ} 34^{\prime} \mathrm{N}$ to $27^{\circ} 45^{\prime} \mathrm{N}$ and $84^{\circ} 19^{\prime} \mathrm{E}$ to $84^{\circ} 29^{\prime} \mathrm{E}$ with altitudinal variation of 181 to $271 \mathrm{~m}$ a.s.l. [28]. The temperature rises up to 34 degree Celsius in the summer (May) and decreases to 7 degree Celsius in the winter (January) with $1,993 \mathrm{~mm}$ average annual rain fall [4]. The temperature of the study site varied from 13 to 29 degree Celsius in March (i.e. warm climate), 18 to 33 degree Celsius in April and 
21 to 34 degree Celsius in May (i.e. warmest climate). Total precipitation was 35 $\mathrm{mm}$ (1.4 inch) in single day of March, $83 \mathrm{~mm}$ (3.3 inch) in 2 days of April and $188 \mathrm{~mm}$ (7.4 inch) in 4 days of the month May. Therefore, the fluctuations in temperature and rain fall affect in vegetations, fruiting plants, cultivating crops [5] [27] [29] [30] [31] and in/vertebrate animal species [8] [32] [33] [34].

The lack of use of pesticides and dumping of kitchen garbage (organic wastes) in the field also increase insect populations which attract wild birds and mammals. The fruiting trees, bushes and vegetables like java plum, china berry, litchi, mango, jack fruits, guava, papaya, pumpkins, bitter guard etc., planted near the edge of crop fields and adjoining houses create suitable environment to get foods and tin roofs provide safety hiding places during heavy rain and falling of hailstones. The cemented poles and extended electric wires also provide roosting place for birds and bushes provide hiding place for mammals. The fallowing of soil exposes plenty of invertebrates and provides food temporarily for birds like crow, cattle egret, myna, starling, drongo, dove, pigeon etc. Yet, it creates sudden and very unstable environment during cultivation and harvesting.

\subsubsection{Data Collection and Analysis}

The identification of species diversity of birds and mammals, their behaviors and public and/or environmental importance were recorded from a home point. The animal species were observed and listed in "Observation Data Sheet" thrice daily (i.e. continuous sitting of 1-2 hours at 7 and 11 AM, and 2 PM) for 2 months beginning from 24 March to 23 May 2020 in the period of lockdown of COVID-19. The photographs and/or videos were taken except one of the species of bats (i.e. Myotis formosus) and six species of Birds (i.e. Aegithina tiphia, Tadorna ferruginea, Ixobrychus cinnamomeus, Coracina macei, Delichon nipalense and Turdoides earlei) which were flying swiftly over the sky in $70 \mathrm{~m}$ in diameter of the home point. The species of these birds and mammals were identified with photographic comparisons and using peculiar characteristics as given in [35] [36] [37] [38] [39] for birds and [3] [40] [41] [42] [43] [44] for mammals. The free search from Wikipedia and Animal Diversity Web (ADW) was performed to confirm taxonomic categories. The range of recorded number of a species was listed in each time. The types of behaviors like feeding, courtship and nesting, aggression and defense, parental care, conflicts and their public (i.e. carrier of zoonotic diseases, crop damage, pollination etc.) and environmental importance (i.e. indicator of pollution free environment, as scavenger etc.) were recorded to analyze using MS-Excel. The impact of daily weather such as temperature, rain and daylight was also considered to influence in regular activities of birds and mammals as the animals appeared infrequently in raining and dusky days.

\section{Results}

\subsection{Species Diversity and National Status}

From my study, total 83 species, 53 genera and 37 families of wild birds and 6 species, 5 genera and 3 families of wild mammals were reported (Tables 1-3). 
Table 1. Checklists of birds with families, genera, species, common and Nepali names with national status.

\begin{tabular}{|c|c|c|c|c|c|c|c|c|}
\hline SN & Code & Family & Genus & Species & Common name & Local name & $\begin{array}{c}\text { National } \\
\text { Status } \\
{[24][35]}\end{array}$ & $\begin{array}{c}\text { Observed } \\
\text { number at } \\
\text { a time }\end{array}$ \\
\hline 1 & 21 & Accipitridae & Accipiter & badius & Shikra & Sikra & LC & 1 to 10 \\
\hline 2 & 22 & Accipitridae & Circus & cyaneus & Hen Harrier & Challa-chor Bhuichil & CR & 1 to 10 \\
\hline 3 & 69 & Aegithinidae & Aegithina & tiphia & Common Lora & Suseli Chari & LC & 1 to 10 \\
\hline 4 & 34 & Alcedinidae & Megaceryle & lugubris & Crested Kingfisher & Thulo-chhirbire Matikor & LC & 1 to 10 \\
\hline 5 & 35 & Alcedinidae & Halcyon & pileata & Black-caped Kingfisher & Kalo-tauke Matikor & LC & 1 to 10 \\
\hline 6 & 33 & Anatidae & Tadorna & ferruginea & Ruddy Shelduck & Chakhewa Chakhewi & NT & 1 to 10 \\
\hline 7 & 67 & Apodidae & Apus & affinis & House Swift & Phirphire Gauthali & LC & 1 to 10 \\
\hline 8 & 46 & Ardeidae & Bubulcus & ibis & Cattle Egret & Bastu Bakulla & LC & 1 to 10 \\
\hline 9 & 47 & Ardeidae & Ixobrychus & cinnamomeus & Cinnamom Bittern & Rato Junbakulla & LC & 1 to 10 \\
\hline 10 & 41 & Campephagidae & Coracina & macei & Large Cuckooshrike & Latushak Birahichari & LC & 1 to 10 \\
\hline 11 & 43 & Chloropseidae & Chloropsis & hardwickii & Orange-billed Leafbird & Swornodar Haritchari & $\mathrm{LC}$ & 1 to 10 \\
\hline 12 & 32 & Ciconidae & Leptoptilos & javanicus & Lesser Adjutant & Bhudifor Garud & VU & 1 to 10 \\
\hline 13 & 48 & Ciconidae & Anastomus & ascitans & Asian Openbill & Ghungifor Garud & LC & 1 to 10 \\
\hline 14 & 54 & Cisticolidae & Orthotomus & sutorius & Common Tailorbird & Paat-siune Fisto & LC & 1 to 10 \\
\hline 15 & 7 & Columbidae & Stigmatopelia & senegalensis & Laughig Dove & Dhusar Dhukur & $\mathrm{LC}$ & 1 to 10 \\
\hline 16 & 16 & Columbidae & Streptopelia & orientalis & Oriental Turtle Dove & Tame Dhukur & LC & 1 to 10 \\
\hline 17 & 17 & Columbidae & Streptopelia & decaocto & Eurasian-collared Dove & Kanthe Dhukur & LC & 1 to 10 \\
\hline 18 & 18 & Columbidae & Stigmatopelia & chinensis & Spotted Dove & Kurle Dhukur & LC & 1 to 10 \\
\hline 19 & 44 & Columbidae & Streptopelia & tranquebarica & Red-collared Dove & Sanotame Dhukur & LC & 1 to 10 \\
\hline 20 & 77 & Columbidae & Columba & livia & Common Pigeon & Parewa & LC & 1 to 10 \\
\hline 21 & 78 & Columbidae & Treron & phoenicoptera & Yellow-footed Green Pigeon & Halesho & LC & 1 to 10 \\
\hline 22 & 15 & Coracidae & Coracias & benghalensis & Indian Roller & Theuwa & LC & 1 to 10 \\
\hline 23 & 11 & Corvidae & Corvus & macrorhynchos & Black Crow & Kalo Kaag & LC & 1 to 10 \\
\hline 24 & 12 & Corvidae & Corvus & splendens & House Crow & Ghar Kaag & LC & 1 to 10 \\
\hline 25 & 29 & Corvidae & Dendrocitta & vagabunda & Rufous Treepie & Kokale & LC & 1 to 10 \\
\hline 26 & 58 & Corvidae & Dendrocitta & formosae & Grey Treepie & Pahadi Kokale & $\mathrm{LC}$ & 1 to 10 \\
\hline 27 & 9 & Cuculidae & Centropus & sinensis & Greater Coucal & Thode Gokul & LC & 1 to 10 \\
\hline 28 & 10 & Cuculidae & Eudynamys & scolopaceus & Asian Koel & Koili & LC & 1 to 10 \\
\hline 29 & 63 & Cuculidae & Centropus & bengalensis & Lesser Coucal & Sano Caucal & LC & 1 to 10 \\
\hline 30 & 49 & Dicaeidae & Dicaeum & erythrorhynchus & Pale-billed Flowerpecker & Rato-thude Puspakokil & $\mathrm{LC}$ & 1 to 10 \\
\hline 31 & 13 & Dicruridae & Dicrurus & macrocercus & Black Drongo & Kalochibe & LC & 1 to 10 \\
\hline 32 & 14 & Dicruridae & Dicrurus & leucophaeus & Ashy Drongo & Dhwase Chibe & LC & 1 to 10 \\
\hline 33 & 55 & Dicruridae & Dicrurus & aeneus & Bronzed Drongo & Sano Chibe & LC & 1 to 10 \\
\hline 34 & 56 & Dicruridae & Dicrurus & caerulescens & White-bellied Drongo & Seto-pete Chibe & LC & 1 to 10 \\
\hline 35 & 53 & Estrildidae & Amandava & amandava & Red Avadavat & Rato Munia & NT & 1 to 10 \\
\hline
\end{tabular}




\section{Continued}

\begin{tabular}{|c|c|c|c|c|c|c|c|c|}
\hline 36 & 52 & Estrildidae & Lonchura & punctulata & Scaly-breasted Munia & Katero Munia & LC & 1 to 10 \\
\hline 37 & 79 & Estrildidae & Lonchura & striata & White-rumped Munia & Seto-dhade Munia & LC & 1 to 10 \\
\hline 38 & 71 & Fringillidae & Carpodacus & erythrinus & Common Rosefinch & Amonga Titu & LC & 1 to 10 \\
\hline 39 & 24 & Hirundinidae & Delichon & nipalense & Nepal House-martin & Ghar Gauthali & LC & 1 to 10 \\
\hline 40 & 30 & Lanidae & Lanius & schach & Long-tailed Shrike & Bhadrai & LC & 1 to 10 \\
\hline 41 & 31 & Lanidae & Lanius & vittatus & Bay-backed Shrike & Chitrak Bhadrai & LC & 1 to 10 \\
\hline 42 & 36 & Megalaimidae & Megalaima & haemacephala & Coppersmith Barbet & Mil Chara & LC & 1 to 10 \\
\hline 43 & 37 & Megalaimidae & Megalaima & asiatica & Blue-throated Barbet & Kuthurke & LC & 1 to 10 \\
\hline 44 & 68 & Megalaimidae & Megalaima & zeylanica & Brown-headed Barbet & Kum-chhirke Kuthurke & $\mathrm{LC}$ & 1 to 10 \\
\hline 45 & 80 & Meropidae & Merops & orientalis & Green Bee-eater & Murali Chara & LC & 1 to 10 \\
\hline 46 & 81 & Meropidae & Merops & philippinus & Blue-tailed Bee-eater & Nilpuchhre Muralichara & LC & 1 to 10 \\
\hline 47 & 82 & Meropidae & Merops & leschenaulti & Chestnut-headed Bee-eater & Katus-tauke Muralichara & LC & 1 to 10 \\
\hline 48 & 26 & Monarchidae & Terpsiphone & paradisi & Asian-paradise Flycatcher & Dhage Chara & LC & 1 to 10 \\
\hline 49 & 27 & Muscicapidae & Copsychus & saularis & Oriental Magpie Robin & Dhobini Chari & LC & 1 to 10 \\
\hline 50 & 28 & Muscicapidae & Copsychus & malabaricus & White-rumped Shama & Syama & LC & 1 to 10 \\
\hline 51 & 50 & Muscicapidae & Hodgsonius & phoenicuroides & White-bellied Redstart & Seto-pete Khanjari & LC & 1 to 10 \\
\hline 52 & 57 & Muscicapidae & Saxicoloides & fulicatus & Indian Robin & Debi Syama & LC & 1 to 10 \\
\hline 53 & 39 & Nectariniidae & Aethopyga & siparaja & Crimson Sunbird & Sipraja Bungecharo & LC & 1 to 10 \\
\hline 54 & 1 & Oriolidae & Oriolous & xanthornus & Black-hooded Oriole & Kalotauke Sunchari & LC & 1 to 10 \\
\hline 55 & 40 & Oriolidae & Oriolous & tenuirostris & Sleder-billed Oriole & Tikhothude Sunchari & LC & 1 to 10 \\
\hline 56 & 74 & Oriolidae & Oriolous & oriolus & Eurasian Golden Oriolle & Gajale Sunchari & LC & 1 to 10 \\
\hline 57 & 51 & Passeridae & Passer & domesticus & House Sparrow & Ghar Bhangera & LC & 1 to 200 \\
\hline 58 & 70 & Passeridae & Passer & montanus & Eurassian Tree Sparrow & Rukh Bhangera & $\mathrm{LC}$ & 1 to 200 \\
\hline 59 & 19 & Ploceidae & Ploceus & bengalensis & Black-breasted Weaver & Chhati-kale Topchara & VU & 1 to 20 \\
\hline 60 & 59 & Ploceidae & Ploceus & manyar & Streaked Weaver & Dharke Topchara & $\mathrm{LC}$ & 1 to 20 \\
\hline 61 & 72 & Ploceidae & Ploceus & philippinus & Baya Weaver & Baya Topchara & NT & 1 to 20 \\
\hline 62 & 75 & Ploceidae & Ploceus & megarhynchus & Finn's Weaver & Sunaolo Topchara & CR & 1 to 20 \\
\hline 63 & 4 & Psittasidae & Psittacula & krameri & Rose-ringed Parakeet & Kanthe Suga & LC & 1 to 20 \\
\hline 64 & 20 & Psittasidae & Psittacula & cyanocephala & Plum-headed Parakeet & Tuisi Suga & LC & 1 to 20 \\
\hline 65 & 83 & Psittasidae & Psittacula & roseata & Blossom-headed Parakeet & Gulafi-tauke Suga & NT & 1 to 20 \\
\hline 66 & 5 & Pycnonotidae & Pycnonotus & cafer & Red-vented Bulbul & Jureli & LC & 1 to 10 \\
\hline 67 & 6 & Pycnonotidae & Pycnonotus & jocosus & Red-whiskered Bulbul & Swet-wakshak Jureli & $\mathrm{LC}$ & 1 to 10 \\
\hline 68 & 65 & Pycnonotidae & Hypsipetes & leucocephalus & Black Bulbul & Bakhre Jureli & LC & 1 to 10 \\
\hline 69 & 64 & Sittidae & Trichodroma & muraria & Wallcreeper & Murari Putalichara & LC & 1 to 10 \\
\hline 70 & 2 & Sturnidae & Acridotheres & tristis & Common Myna & Dangre Rupi & LC & 1 to 20 \\
\hline 71 & 3 & Sturnidae & Sturnia & pagodarum & Brahminy Starling & Jure Sarau & LC & 1 to 10 \\
\hline 72 & 8 & Sturnidae & Sturnus & contra & Asian Pied Starling & Dangre Sarau & LC & 1 to 10 \\
\hline
\end{tabular}




\section{Continued}

\begin{tabular}{|c|c|c|c|c|c|c|c|c|}
\hline 73 & 25 & Sturnidae & Acridotheres & fuscus & Jungle Myna & Ban Rupi & LC & 1 to 10 \\
\hline 74 & 42 & Sturnidae & Gracula & religiosa & Common Hill Myna & Myna & LC & 1 to 10 \\
\hline 75 & 61 & Sturnidae & Acridotheres & ginginianus & Bank Myna & Bhid Rupi & LC & 1 to 10 \\
\hline 76 & 66 & Sturnidae & Sturnus & malabaricus & Chestnut-tailed Starling & Fushro-tauke Sarau & LC & 1 to 10 \\
\hline 77 & 76 & Sylvidae & Sylvia & curruca & Lesser Whitethroat & Swet-kantha Fisto & LC & 1 to 10 \\
\hline 78 & 23 & Threskiornithidae & Pseudibis & papillosa & Black Ibis & Karraa Sawari & LC & 1 to 10 \\
\hline 79 & 60 & Timalidae & Turdoides & striata & Jungle Babbler & Bagale Bhyakur & LC & 1 to 10 \\
\hline 80 & 62 & Timalidae & Turdoides & earlei & Striated Babbler & Khar Bhyakur & LC & 1 to 10 \\
\hline 81 & 45 & Tytonidae & Tyto & capensis & Grass Owl & Ghanse Latokosero & LC & 1 to 10 \\
\hline 82 & 73 & Tytonidae & Tyto & $a l b a$ & Barn Owl & Gothe Latokosero & VU & 1 to 10 \\
\hline 83 & 38 & Upupidae & Upupa & epops & Common Hoopoe & Kapre Chara & LC & 1 to 10 \\
\hline \multicolumn{2}{|c|}{ Total } & 37 & 53 & 83 & & & & \\
\hline
\end{tabular}

Table 2. Checklists of mammals with families, genera, species, common and Nepali names with National status.

\begin{tabular}{|c|c|c|c|c|c|c|c|c|}
\hline SN & Code & Family & Genera & Species & Common Name & Nepali Name & $\begin{array}{c}\text { National } \\
\text { Status [3] } \\
{[40]}\end{array}$ & $\begin{array}{c}\text { Observed } \\
\text { number at a } \\
\text { time }\end{array}$ \\
\hline 1 & 1 & Canidae & Canis & aureus & Golden Jackal & Shyal & LC & 1 to 8 \\
\hline 2 & 2 & Canidae & Vulpus & bengalensis & Bengal fox & Phyauro & VU & 1 to 2 \\
\hline 3 & 3 & Herpestidae & Herpestes & edwardsii & Grey Mongoose & Khairo Nyauri Musa & $\mathrm{LC}$ & 1 to 4 \\
\hline 4 & 4 & Herpestidae & Herpestes & javanicus & Small Asian Mongoose & Sano Nyauri Musa & LC & 1 to 4 \\
\hline 5 & 5 & Vespertilionidae & Pipistrellus & tenuis & Least Pipistrelle & Sano Chamero & LC & 1 to 5 \\
\hline 6 & 6 & Vespertilionidae & Myotis & formosus & Hodgson's bat & Hodgson ko Chamero & LC & 1 to 10 \\
\hline \multicolumn{2}{|c|}{ Total } & 3 & 5 & 6 & & & & \\
\hline
\end{tabular}

Table 3. Total families, genera and species of birds and mammals with their National status.

\begin{tabular}{|c|c|c|c|c|c|c|c|c|c|}
\hline \multirow{2}{*}{ SN } & \multirow{2}{*}{ Animals } & \multirow{2}{*}{ Family } & \multirow{2}{*}{ Genus } & \multirow{2}{*}{ Species } & \multicolumn{4}{|c|}{ National status [3] [24] [35] [40] } & \multirow{2}{*}{ Total } \\
\hline & & & & & $\mathrm{CR}$ & NT & VU & LC & \\
\hline 1 & Birds & 37 & 53 & 83 & 2 & 4 & 3 & 74 & 83 \\
\hline 2 & Percentage & & & & 2.41 & 4.82 & 3.61 & 89.16 & 100 \\
\hline 3 & Mammals & 3 & 5 & 6 & 0 & 0 & 1 & 5 & 6 \\
\hline \multirow[t]{2}{*}{4} & Percentage & & & & 0 & 0 & 16.67 & 83.33 & 100.00 \\
\hline & Total & 40 & 58 & 89 & 2 & 4 & 4 & 79 & 89 \\
\hline
\end{tabular}

Among the genera of birds, Dicrurus and Ploceus were recorded the highest 7.54\% (4/53); followed by Acridotheres, Megalaima, Merops, Oriolus, Psittacula and Streptopelia with 5.66\% (3/53), and remaining twelve genera i.e. Centropus, Copsychus, Corvus, Dendrocitta, Lanius, Lonchura, Passer, Pycnonotus, Stig- 
matopelia,Sturnus, Tyto and Turdoides; were recorded 3.77\% (2/53). Similarly, thirty three genera i.e. Accipiter, Aegithina, Aethopyga, Amandava, Anastomus, Apus, Bubulcus, Carpodacus, Chloropsis, Circus, Columba, Coracias, Coracina, Delichon, Dicaeum, Eudynamys, Gracula, Halcyon, Hodgsonius, Hypsipetes Ixobrychus, Leptoptilos, Megaceryle, Orthotomus, Pseudibis, Saxicoloides, Sturnia, Sylvia, Tadorna, Terpsiphone, Treron, Trichodroma and Upupa were recorded 1.88\% (1/53). Likewise, 33.33\% (2/6) of Herpestes spp.; and 16.66\% (1/6) of each Canis aureus, Vulpes bengalensis, Pipistrellus tenuis and Myotis formosus were recorded among mammals. The number of birds observed at a time were in the range of 1-200 (sparrows); 1-20 (common myna, weaver birds and parakeets); and remaining 1-10 (Table 1); and 1-4 (Herpestes spp.); 1-2 (Vulpes bengalensis); 1-8 (Canis aureus); 1-5 (Pipistrellus tenuis); and 1-10 (Myotis formosus) were among mammals (Table 2). Similarly, the reported birds were CR $2.41 \%(2 / 83)$, NT $4.82 \%$ (4/83), VU 3.61\% (3/83), and LC $89.16 \%(74 / 83)$ of National status[24] [35] and in mammals only two categories of National status [3] [40] VU 16.67\% (1/6) and LC 83.33\% (5/6) were reported (Table 3).

\subsection{Behaviors Observed}

Well specialized behaviors of birds and mammals were recorded such as feeding and territory (Figures 1-3), courtship and mating (Figure 4), nesting and parental care (Figure 5), aggression, defense and conflict behaviors (Figure 6). These animals were also reported as environmental indicators (presence of swallows, bee-eater and weaver birds indicated pre-monsoon and monsoon), pollinators (humming birds, sunbirds, weaver birds, bats etc.) [15] and carrier or host of zoonotic diseases (e.g. jackals, foxes, mongoose, bats etc.) like skin disease, parasitic (protozoan, toxocariasis, helminthiasis etc.), bacterial and viral infections (e.g. rabies, foot and mouth disease etc.) [30] [45] [46] [47]. Yet, the animal behaviors were affected by diverse factors such as sudden change in crop fields and micro-ecosystem due to cultivation and harvesting, temperature fluctuations and rain fall, growth of fruiting plants and vegetables as well as human activities.

\subsubsection{Feeding and Territorial Behaviors}

Both birds and mammals were established territory for feeding and forages (Figures 1-3) shaping with their experience, health and body size. The rubbing of snouts and urination in the plant stocks and walls as well as markings on the ground were made to fix the territory. The birds like coppersmith, coucal, drongo, crow, dove, humming bird, weaver bird, bee-eaters, shrike, bulbul and jungle babblers etc., produced diverse sounds to grab opportunity for feeding and to keep space. Similarly, natural behavior patterns were observed in small and medium sized mammals like bengal fox, golden jackals, bats etc., to establish feeding and foraging space. These animals were more active after rain, at morning (after $7 \mathrm{AM}$ ), at noon (after $11 \mathrm{AM}$ ) and early evening (after $2 \mathrm{PM}$ ). The birds were observed feeding even at 6.45 PM (e.g. coppersmith), at 7:20 PM (e.g. barn 


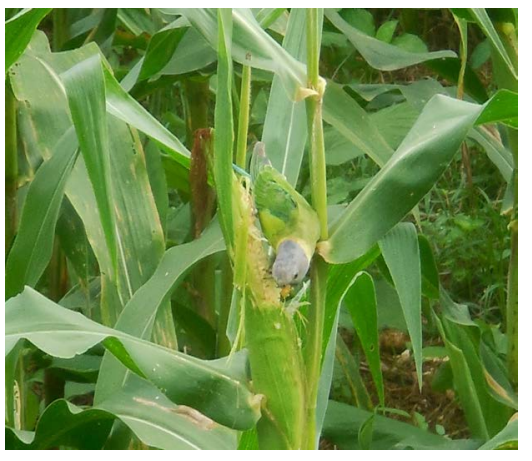

(a)

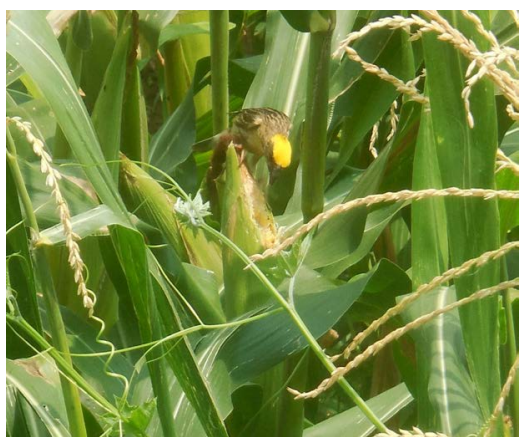

(c)

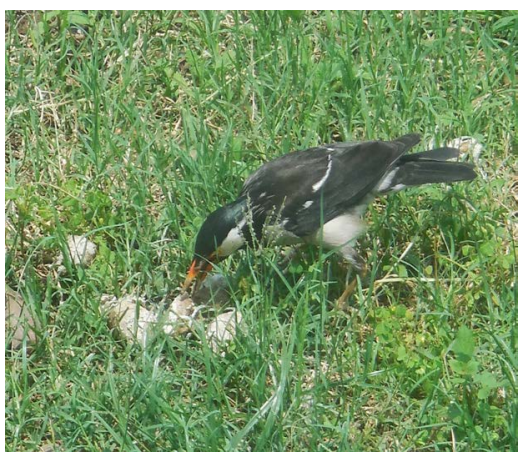

(e)

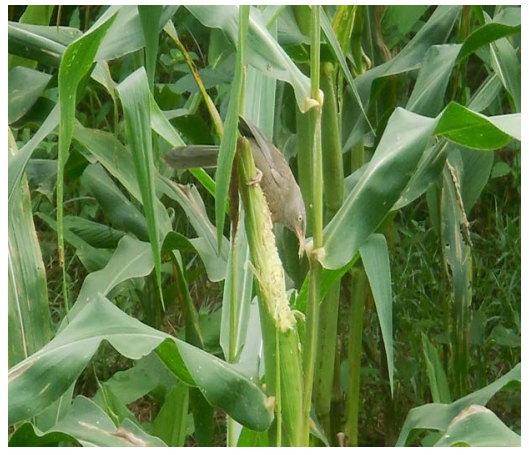

(b)

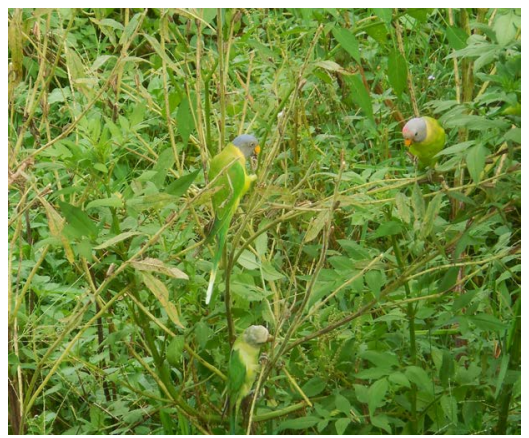

(d)

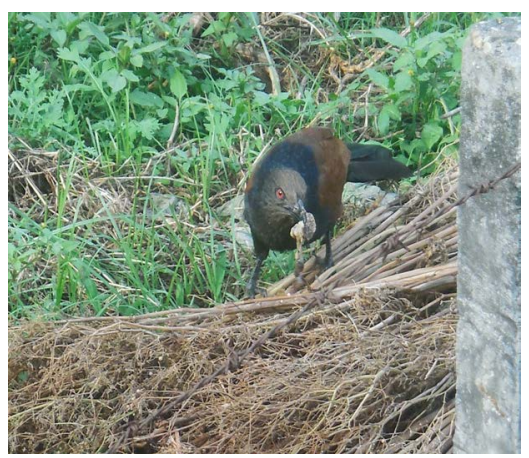

(f)

Figure 2. Feeding behavior of birds: Inter species interactions for feeding among Blossom-headed Parakeet (a), Jungle babbler (b) and Streaked weaver (c). Blossom-headed parakeets eating Sesame oil seeds as alternative food just $6 \mathrm{~m}$ down to "a home point" (d), Asian Pied Myna (coprophagous) eating Jackal feces (e) and Greater Coucal (f) eating Giant African Snail (i.e. an exotic crop pest).

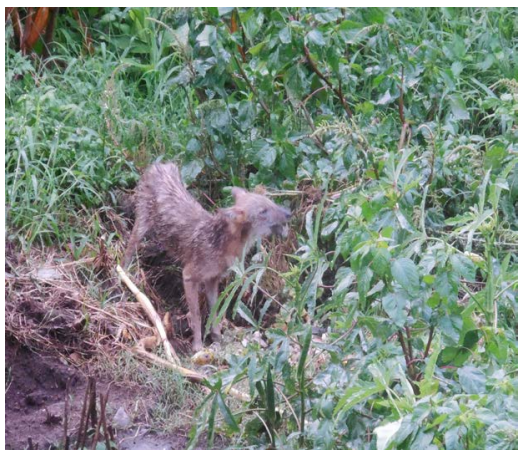

(a)

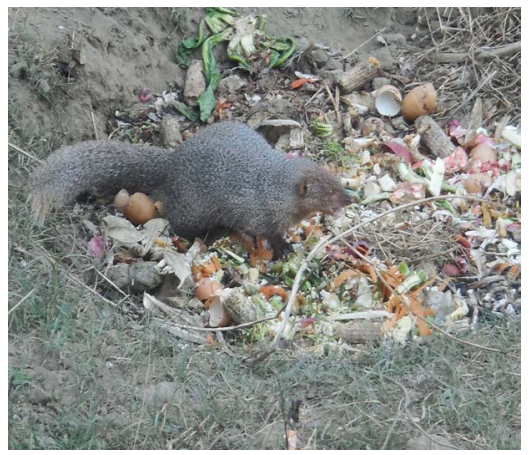

(b) 


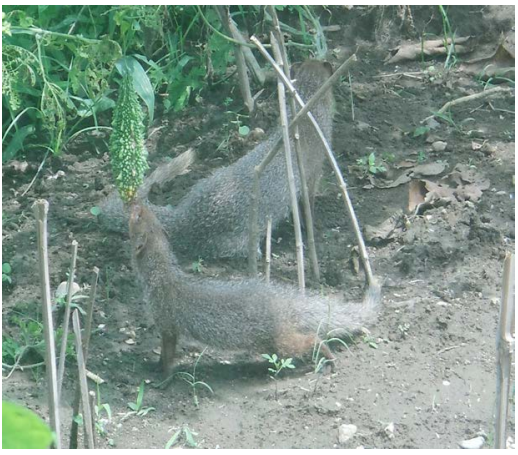

(c)

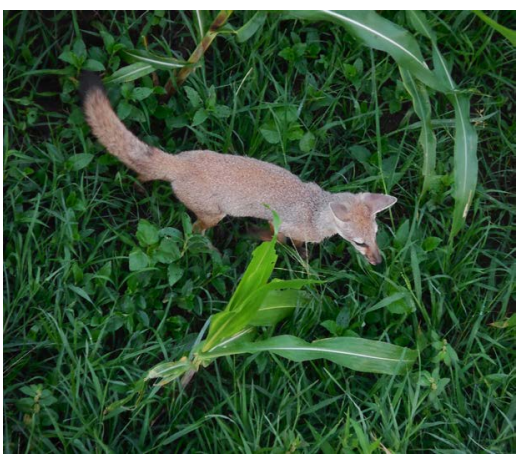

(e)

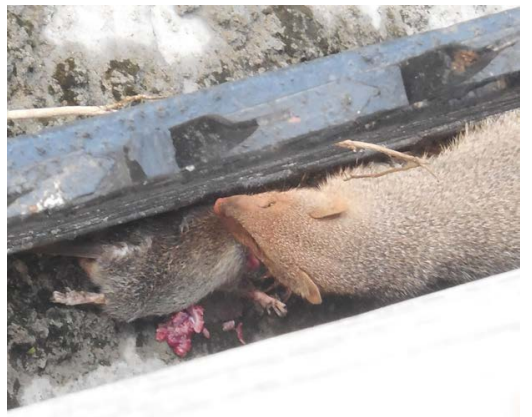

(d)

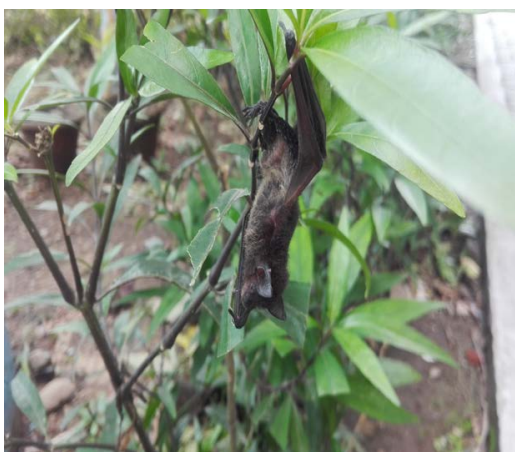

(f)

Figure 3. Feeding behavior of mammals: Golden Jackal (a) and Grey mongoose (b) eating kitchen garbage, baby Grey Mongoose testing food (c), Small Asian Mongoose eating a mouse (d) a crop pest, Bengal Fox (e) eating small in/vertebrates and Least Pipistrelle bat (f) on rest.

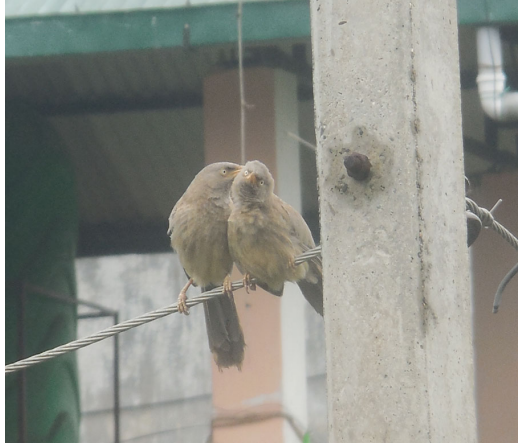

(a)

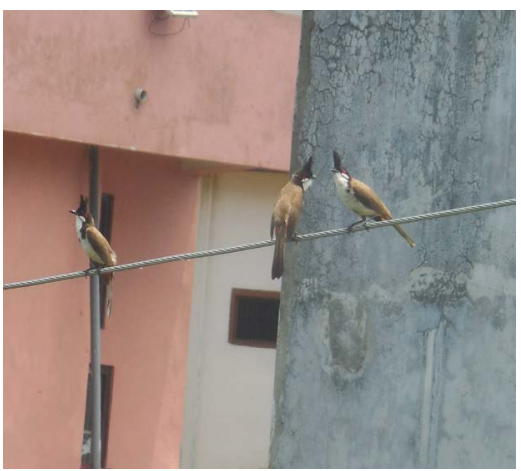

(c)

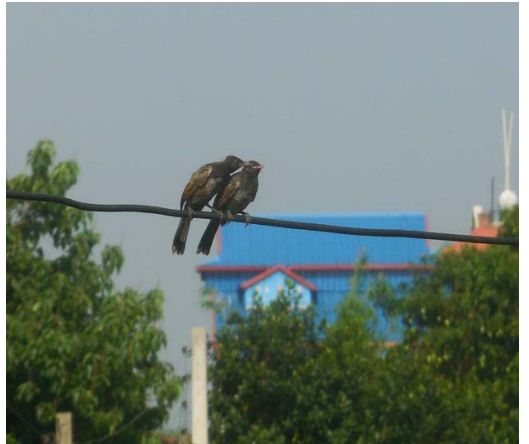

(b)

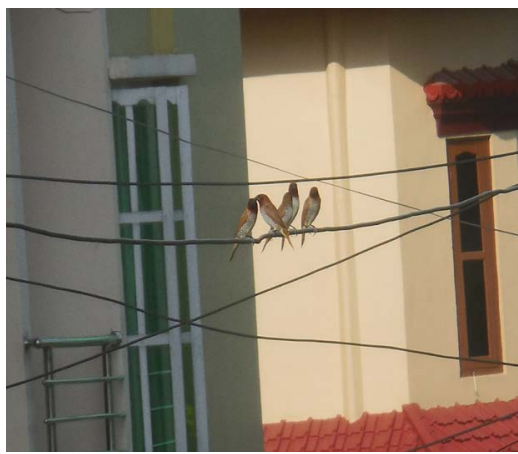

(d) 


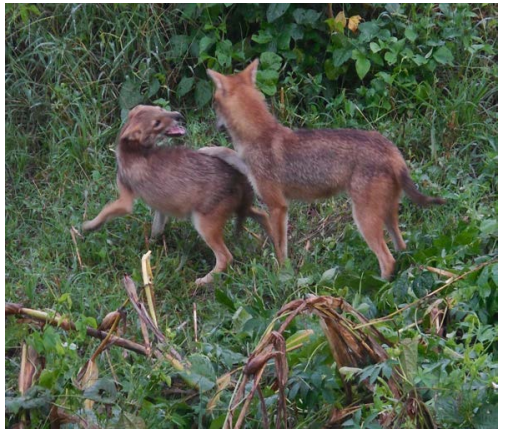

(e)

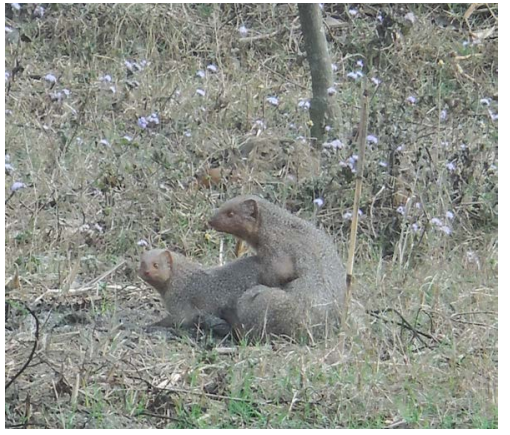

(f)

Figure 4. Courtship display and mating behaviors: Jungle Babblers (a), Red-vented Bulbuls (b), Red-whiskered Bulbuls (c) and Scaly-breasted Munia (d) among birds and Golden Jackals (e) among mammals are in courtship display where as Grey Mongooses are mating (f).

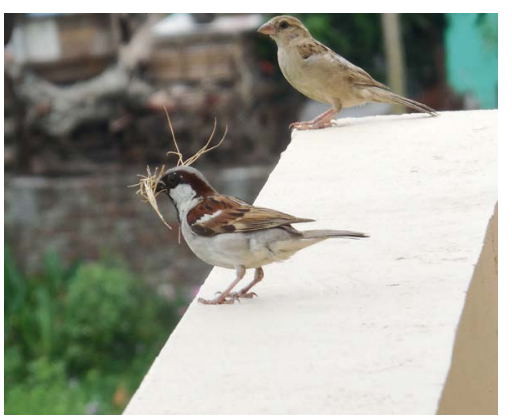

(a)

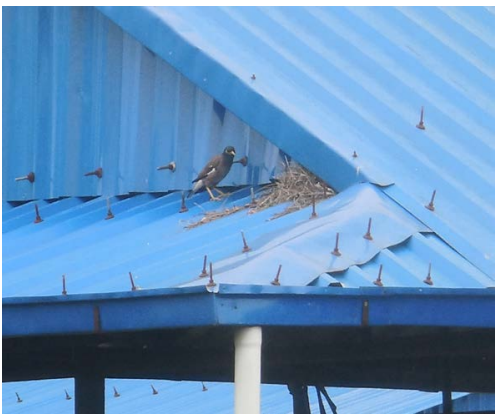

(c)

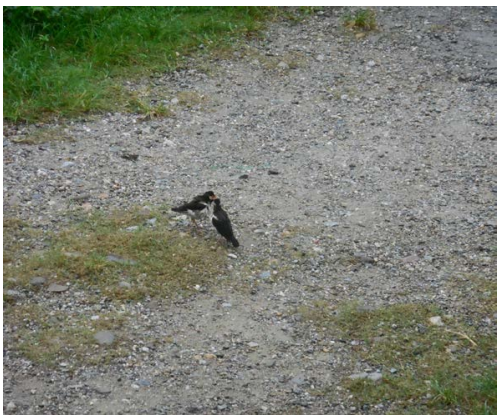

(e)

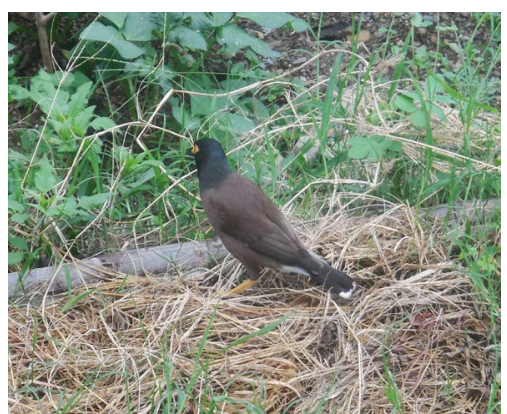

(b)

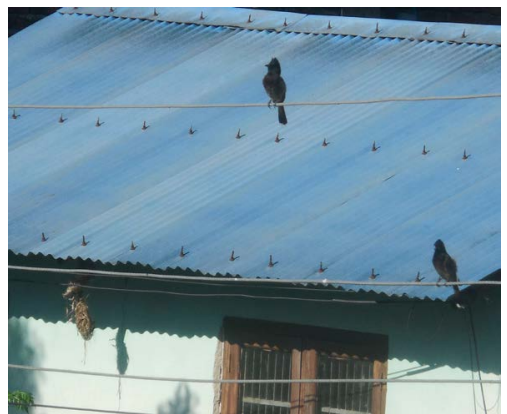

(d)

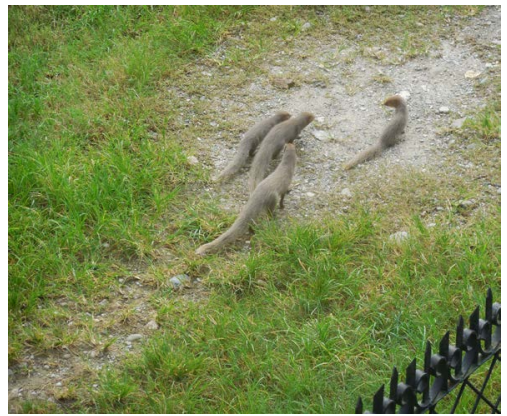

(f)

Figure 5. Nesting behaviors and parental care: House sparrows (a) and Jungle Myna (b) collecting nesting grasses, Common Myna (c) and Red-vented Bulbul (d) built nests under tin roofs, Asian Pied-starling feeding to its juvenile (e) and Grey Mongooses with parental care (f). 


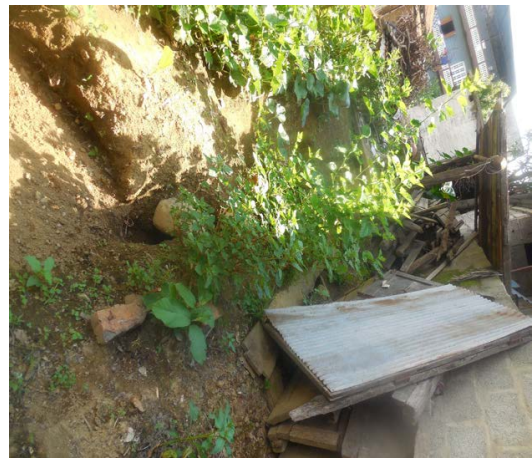

(a)

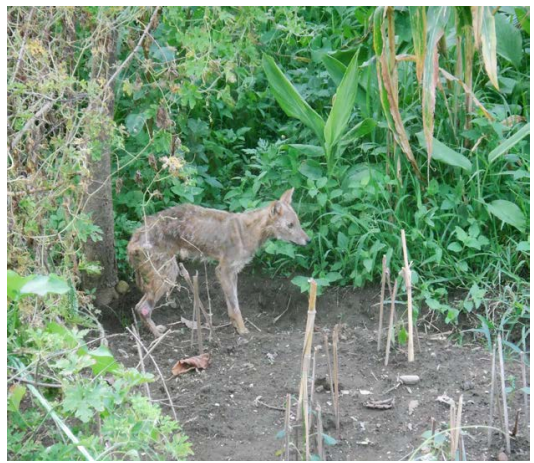

(c)

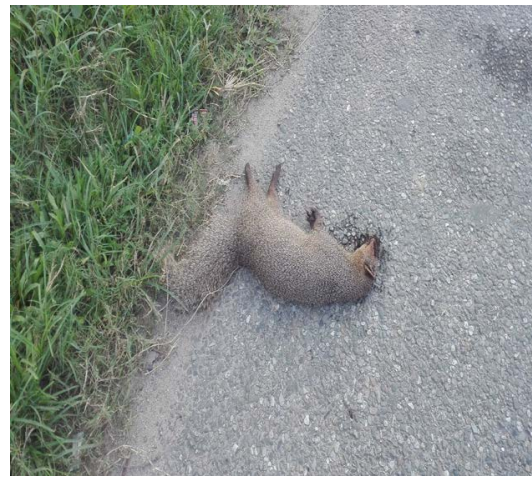

(e)

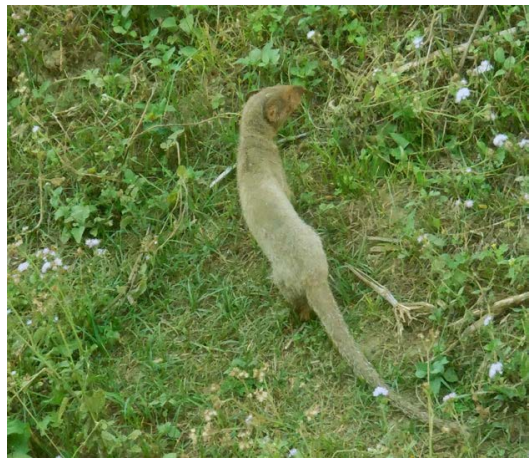

(b)

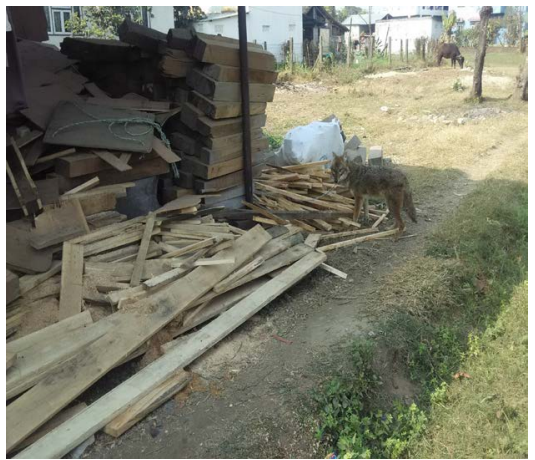

(d)

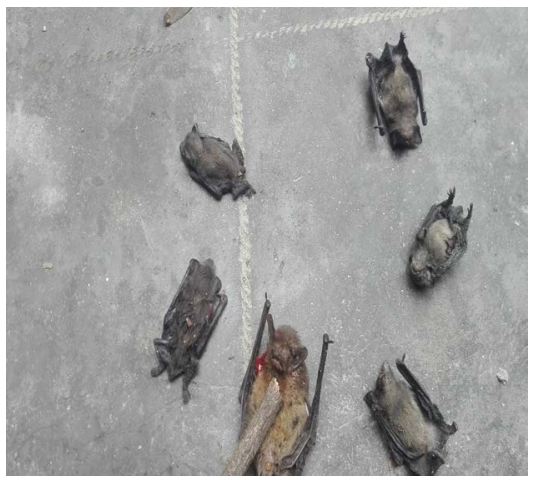

(f)

${ }^{\star}$ Note: The Golden Jackal tied in iron chain (d) was rescued and released by the researcher.

Figure 6. Aggression, defense and conflict behaviors: Living holes of Bengal Fox (a) under furniture, Small Asian Mongoose (b) and Golden Jackal (c) with skin diseases, Golden Jackal (d) tied in iron chain, killed Grey Mongoose (e) and Least Pipistrelle bats (f).

owl) and at 8:25 PM (e.g. grass owl). The jackals and foxes were observed repeatedly after rain (at noon, i.e. $12 \mathrm{PM}$ ) and in the evening (i.e. $9 \mathrm{PM}$ ). However, mongooses were more active in the morning (after $7 \mathrm{AM}$ ), at midday (11 AM to 12 noon) and in the early evening (after $2 \mathrm{PM}$ ).

\subsubsection{Courtship and Mating Behaviors}

Birds produced varieties of sounds to communicate sexual partners for mating. For examples, the male coucals, bulbuls, coppersmith, humming birds, drongo, koels etc., produced high pitched sound to attract females in early morning or in 
the dusky day and rubbed wings or heads and pecked gently to make females ready for frequent mating. In streaked weaver birds, scaly-breasted munia, and jungle babblers, the male often rubbed heads and beaks with female partners for mating.. The jackals and foxes hauled infrequently at evening and night with short choppy sound. Similarly, the mongooses and jackals rubbed their snout with their partners to show closeness and preparedness for mating. The male jackal was riding on the female's body and biting mouth to mouth softly to make involved in sexual activities. Similary, the mongooses were mating in the peaceful midday with careful gestures holding female by male with fore limbs coinciding genitalia from back side and remained in this posture for 5 minutes (Figure 4).

\subsubsection{Nesting and Parental Care}

The favorable season for nesting of birds was recorded in the first week of April for brahminy starlings, common myna, jungle myna and Asian pied myna, bulbuls, orioles, weaver birds, drongo and crows. The brahminy starling made nest in the electric meter box, common myna made nest under the tin roof, the bulbuls made nest with iron pipe under tin roof, Asian pied myna made nest in the cemented electric pillar, weaver birds made nest in the nut and palm tree leaves, and the other birds made nest in the fruiting and tall trees. The second batches were also begun in the third week of June in the same nest of brahminy starling, common myna and Asian pied myna. However, bulbuls, orioles, drongo, and crows nested for single batch. The mongooses and foxes made holes under the furniture or bushes to give birth of babies and Least Pipistrelle bats gave birth in the iron pipes, dark crevices and under tin roofs of the houses. The birds cared babies for more than three weeks where as mammals showed advanced social care until babies develop survival capacity (Figure 5).

\subsubsection{Aggression, Defense and Conflicting Behaviors}

Aggression is an innate behavior of birds and mammals used for shaping hierarchy among members and fixing territory mainly at feeding and sexual activities where as defense is ultimate way of protection. The birds such as drongo, brahminy starlings, crows and shrikes were more aggressive than others to protect babies from predator birds like shikra and hen harrier. These birds had strong pecking and chasing strategy to prevent invaders (i.e. suspected birds and carnivore mammals). The mongooses had three step protection strategies like Stand erect, See and Proceed (SSP). The foxes had elusive strategy and jackals were fearless to gnaw. The anomalous behaviors of jackals to raid poultry and sharing of feeding on organic garbage with different animals like mongooses, foxes, domestic cats, dogs and birds increased chances of transmitting viral, bacterial and parasitic zoonoses. The Asian pied myna was recorded feeding on feces of jackals (Figure 2) that can create socio-economic or health problems in humans through contamination of ripen fruits. The mongooses were recorded killed in the accidents in the streets and least pipistrelle bats were harshly killed in large population (i.e. 6 in number) at once by the people due to nuisance be- 
havior of fecal droppings in the room (Figure 6), as the droppings were laid $1 \mathrm{~m}$ South to my "home point" of study, yet we did not disturb.

\subsection{Factors Affecting Animal Behaviors}

The behaviors of birds and mammals were affected by local environments of the study site. For examples the vegetations, temperatures, rain, pollutions and human activities had a direct impact in animal behaviors. The birds, mongooses, foxes and jackals were active in low temperature of the day (i.e. morning at 7 $\mathrm{AM}$ and in the early evening after $2 \mathrm{PM}$ ), after rain or in the dusky day and during reduced human activities. The visit of birds and mammals was increased at the time of maturation of crops or vegetables and fruiting trees like litchi, mango, java plum, china berry, guava, papaya etc. The fast grown plants due to frequent rain (up to 4 times precipitation in May) and tin roofs that were used as hiding places as well as the kitchen garbage (organic matters) kept in the mud pit lured these animals to fulfill hunger in crisis and lack of pollution or pesticides in this area were prime factors to attract wild animals to the city.

\section{Discussion}

This study reveals 83 species of birds (Table 1 and Table 3) which represents $34.01 \%(83 / 244)$ of urban bird species of Bharatpur [17], 15.28\% (83/543) of birds of Chitwan National Park (CNP) and 9.36\% (83/886) of birds of Nepal [48]. Likewise, 6 species of mammals reported from this study, represent $21.42 \%$ (6/28) of urban mammals of Bharatpur [18], 8.82\% (6/68) mammals of CNP and $2.66 \%(6 / 225)$ mammals of Nepal [48]. The fragmented gardens, bushes, agricultural lands free from pesticides, suitable microhabitat for insects and presence of hiding places in urban houses under tin roofs with availability of organic kitchen wastes of soil pit attracted wild birds and mammals in the urban area [17] [18] [20] [49] [50] [51]. The birds of CR (2.41\%), NT (4.82\%), VU (3.61\%), and a species of mammal (Bengal fox) of the National status VU (16.67\%) (Table 3, Figure 3) were reported in the densely populated city of human which signified great ecological values. Therefore, the urban area is a home for nesting and foraging birds, and temporarily or permanently living mammals.

The animals performed different types of behaviors to handle the situation in their own favors. Courtship and nesting, proper feeding and parental care, aggression and defense, intra-species or inter-species interactions etc., were maintained to balance micro-ecosystem of the locality. For instances, the spathe of maize cobs was removed by parakeets to expose seeds and hence jungle babblers, streaked weaver birds, common myna etc., were fed as an intra-species harmony (Figure 2). The parent birds like drongo, common myna, brahminy starlings, bulbuls, crows, sparrows and shrikes were more aggressive to protect babies with predators like shikra, hen harriers, mongooses, civets and cats. These birds also produced intense sound to warn other species to hide and were furiously chasing predators from their territory. The wild birds and mammals were also shifting 
their behavior to adapt in the same urban areas due to opportunity of food selection. The habitat and food overlaps were also reported among species of jackals, and between foxes and jackals as reported by [52] [53]. Ten species of birds (i.e. bulbul, common myna, Asian pied starling, brahminy starling, house sparrow, crow, dove, pigeon, Eurasian golden oriole, and weaver birds) made nests near or at the human houses, in the cemented pillars or in electric meter box etc. (Figure 5) that indicated favorable environment in terms of getting nesting materials and foods (i.e. crops, fruits, grasses, in/vertebrates etc.) for their babies mainly in rainy season (April to July). Three species of mammals (i.e. a species of Bengal fox and two species of mongooses) also made den and/or holes under the tin roofs or furniture of human settlement area. Hence, the mesopredators were adapted in the city to be safe from large predators like leopards; tigers etc., of the PAs, and the urban people were gradually accepting wildlife presence in human habitat for their protection in sympatric association.

The birds and mammals were useful in control of in/vertebrate pests as biodiversity effects on function of ecosystem [54]. For examples the coucal birds were found eating on Giant African snail (Achatina fulica) which are exotic mollusk pests of crops, fruiting trees and vegetables. The shrikes, drongo, bee-eaters, common myna, oriental magpie robins, brahmini starlings etc., controlled grass hoppers, locusts, and other insects (pollinators) that increased agricultural production [55]. The martins, weavers and bee-eater birds were also useful to indicate commencement of pre-monsoon and monsoon. The granivoreous (weavers, house sparrow etc.), frugivorous (parakeets, coucal etc.), and nectivorous (sunbirds, bulbuls etc.) birds were spreading seeds and pollinating plants (i.e. papaya, guava, maize, sesame etc.) as bats and humming birds pollinate flowering and fruiting plants [56] [57]. Hence, birds and mammals are major agents of pollination [58]. The small (e.g. mongoose) to medium sized mammals (e.g. foxes, jackals) and birds (e.g. coucal, crows, shikra, hen harriers etc.) were controlling crop pests like insects and rodents due to selection habit of diets and foods [59] and also were controlling pollutants like kitchen garbage (Figure 1 and Figure 3).

The presence of migratory or residential birds (Asian pied myna, coucal, bee-eater, weavers, shikra, etc.); and mammals (bats, foxes, jackals etc.); in the human locality [18] [60] alarms for zoonotic diseases like viral (H5N1 virus, rabies, foot and mouth disease etc.) [30] [45], bacterial (tuberculosis), and parasitic diseases (helminthiasis, skin disease etc.) due to overlap of habitat and diets [40] that can transmit to people through their stools and droppings of saliva in raw edible vegetables and ripen fruits like papaya, guava etc. The birds (i.e. coucal, crow, sparrow etc.) and mammals harbor different protozoan and helminthes parasites [45] [46], and their modes of transmission in the community people is yet to verify.

\section{Conclusion}

The existence of significant number of wild birds and mammals in a small hu- 
man settlement area of Bharatpur Metropolitan City in lock down of COVID-19, indicates sympatric association of animals with humans although their innate behaviors were not sufficient to endure frequent and unpredicted challenges to save life. These animals were adapted to build nests or dens in or near human houses, feeding on anthropogenic plant productions (e.g. fruits, crops, vegetables etc.), kitchen garbage, poultry and small in/vertebrates. Therefore, the coprophagous (Figure 2) and other birds and mammals were connected in different aspects of human life to act as pollen vectors, monsoon and pesticide indicators, scavengers, local ecosystem regulator, and as carrier or host of viral, bacterial or parasitic zoonoses in addition to their own safety from human conflicts and large predators.

\section{Conflicts of Interest}

The author declares no conflicts of interest regarding the publication of this paper.

\section{References}

[1] Baral, H.S., Regmi, U.R., Poudyal, L.P. and Acharya, R. (2012) Status and Conservation of Birds in Nepal. https://www.researchgate.net/publication/312233571

[2] Inskip, C., Baral, H.S., Inskipp, T. and Stattersfield, A. (2010) The State of National Birds 2010. Journal of Threatened Taxa, 5, 3475. https://doi.org/10.11609/JoTT.03276.933

[3] Amin, R., et al. (2018) The Status of Nepal's Mammals. Journal of Threatened Taxa, 10, 11361-11378. https://doi.org/10.11609/jott.3712.10.3.11361-11378

[4] Weather Atlas (2020). https://www.weather-atlas.com/en/nepal/bharatpur-climate

[5] Hatfield, J.L. and Prueger, J.H. (2015) Temperature Extremes: Effect on Plant Growth and Development. Weather and Climate Extremes, 10, 4-10. https://doi.org/10.1016/j.wace.2015.08.001

[6] Thakur, S.B. and Karki, G. (2018) Climate Change Impacts on Agriculture and Livestock in Nepal. The Journal of Agriculture and Environment, 19, 108-117. https://www.researchgate.net/publication/326589435

[7] Thomas, P.J., Martin, P. and Boutin, C. (2011) Bush, Bugs, and Birds; Interdependency in a Farming Landscape. The Open Ecology Journal, 1, 9-23. https://doi.org/10.4236/oje.2011.12002

[8] Johnson, C.A., et al. (2016) Effects of Temperature and Resource Variation on Insect Population Dynamics: The Bordered Plant Bug as a Case Study. Functional Ecology, 30, 1122-1131. https://doi.org/10.1111/1365-2435.12583

[9] Shrestha, A. and Baral, S. (2018) Impacts of Climate Change on Livestock and Livestock Produces: A Case Study of Banke District, Nepal. Sarhad Journal of Agriculture, 34, 760-766. https://doi.org/10.17582/journal.sja/2018/34.4.760.766

[10] LEAP (2015) Principles for the Assessment of Livestock Impacts on Biodiversity. Draft for Public Review. Livestock Environmental Assessment and Performance Partnership. FAO, Rome, Italy. http://www.fao.org/3/a-i6492e.pdf

[11] Albuquerque, F.S., Peso-Aguiar, M.C., Assunção-Albuquerque, M.J.T. and Gálvez, L. (2009) Do Climate Variables and Human Density Affect Achatina fulica (Bowditch) (Gastropoda: Pulmonata) Shell Length, Total Weight and Condition Factor? Brazilian Journal of Biology, 69, 879-885. 
https://doi.org/10.1590/S1519-69842009000400016

[12] Barrowclough, G.F., Cracraft, J., Klicka, J. and Zink R.M. (2016) How Many Kinds of Birds Are There and Why Does It Matter? PLoS ONE, 11, e0166307. https://doi.org/10.1371/journal.pone.0166307

[13] Burgin, C.J., Colella, J.P., Kahn, P.L. and Upham, N.S. (2018) How Many Species of Mammals Are There? Journal of Mammalogy, 99, 1-14.

https://doi.org/10.1093/jmammal/gyx147

[14] BCN (2020) Bird Conservation Nepal. https://www.birdlifenepal.org/birds/status-of-birds

[15] Shrestha, T.K. (1997) Mammals of Nepal with Reference to Those of India, Bangaladesh, Bhutan and Pakistan. R.K. Printers, Teku, Kathmandu, Nepal, 53, 330-347.

[16] CNP. (2018) Chitwan National Park (CNP). https://en.wikipedia.org/wiki/Chitwan National Park

[17] Chaudhary, B. (2018) Diversity of Birds in Bharatpur Metropolitan City, Chitwan, Nepal. Vibek, Multi-Disciplinary Peer-Reviewed Journal, 34, 36-49.

[18] Chaudhary, B. (2018) Diversity of Urban Mammals in Bharatpur Metropolitan City, Chitwan, Nepal. BMC Journal of Scientific Research, 2, 7-14.

[19] Dickman, C.R. (1987) Habitat Fragmentation and Vertebrate Species Richness in an Urban Environment. Journal of Applied Ecology, 24, 337-351. https://doi.org/10.2307/2403879

[20] Saito, M. and Koike, F. (2013) Distribution of Wild Mammal Assemblages along an Urban Rural Forest Landscape Gradient in Warm Temperate East Asia. PLoS ONE, 8, e65464. https://doi.org/10.1371/journal.pone.0065464

[21] Bist, B.S., et al. (2017) Mammals: The Jewels of Banpale Forest, Kaski District, Nepal. Journal of Biodiversity \& Endangered Species, 5, 3-6.

[22] DNPWC (2017) Profiling of Protected and Human Wildlife Conflicts Associated Wild Animals in Nepal. Department of National Parks and Wildlife Conservation, Kathmandu, Nepal.

http://dnpwc.gov.np/media/files/Profiling of Protected and Human Wildlife C onflict Associated Wild Aninal in Nepa M87TxjX.pdf

[23] DFRS (2015) State of Nepal's Forests. Forest Resource Assessment (FRA) Nepal, Department of Forest Research and Survey (DFRS). Kathmandu, Nepal. http://frtc.gov.np/downloadfile/state\%20\%20forest\%20of\%20Nepal $1579793749 \quad 15$ 79844506.pdf

[24] Inskipp, C., Baral, H., Inskipp, T. and Stattersfield, A. (2013) The State of Nepal birds 2010. Journal of Threatened Taxa, 5, 3473-3503.

https://doi.org/10.11609/JoTT.03276.933

[25] Thapa, R. (2016) The Burning Issues of Conflict: A Case Study of Chitwan National Park, Nepal. International Journal of Science and Research, 5, 542-547. https://www.researchgate.net/publication/323599589

[26] Acharya, K.P., Paudel, P.K., Neupane, P.R. and Köhl, M. (2016) Human-Wildlife Conflicts in Nepal: Patterns of Human Fatalities and Injuries Caused by Large Mammals. PLoS ONE, 11, e0161717. https://doi.org/10.1371/journal.pone.0161717

[27] Suggitt, A.J., et al. (2014) Microclimate, Climate Change and Wildlife Conservation. British Wildlife, 25,162-168. https://www.researchgate.net/publication/287691240

[28] CD (2018) Chitwan District. https://en.wikipedia.org/wiki/Bharatpur, Nepal

[29] Johansson, R., Luebehusen, E., Morris, B., Shannon, H. and Meyer, S. (2015) Monitoring the Impacts of Weather and Climate Extremes on Global Agricultural Pro- 
duction. Weather and Climate Extremes, 10, 65-71.

https://doi.org/10.1016/j.wace.2015.11.003

[30] Wicker, L.V., Canfield, P.J. and Higgins, D.P. (2017) Potential Pathogens Reported in Species of the Family Viverridae and Their Implications for Human and Animal Health. Zoonoses Public Health, 64, 75-93. https://doi.org/10.1111/zph.12290

[31] Gray, S.B. and Brady, S.M. (2016) Plant Developmental Responses to Climate change. Developmental Biology, 419, 64-77. https://doi.org/10.1016/j.ydbio.2016.07.023

[32] Jaworski, T. and Hilszczański, J. (2014) The Effect of Temperature and Humidity Changes on Insects Development Their Impact on Forest Ecosystems in the Expected Climate Change. Forest Research Papers, 74, 345-355. https://doi.org/10.2478/frp-2013-0033

[33] Sarma, R.R., Munsi, M. and Ananthram, A.N. (2015) Effect of Climate Change on Invasion Risk of Giant African Snail (Achatina fulica, Férussac, 1821: Achatinidae) in India. PLOS ONE, 10, e0143724. https://doi.org/10.1371/journal.pone.0143724

[34] Kiritani, K. (2013) Different Effects of Climate change on the Population Dynamics of Insects. Applied Entomology and Zoology, 48, 97-104. https://doi.org/10.1007/s13355-012-0158-y

[35] Inskipp, C., et al. (2016) The Status of Nepal's Birds: The National Red List Series. Vol. 1-6, Zoological Society of London, UK.

https://www.nationalredlist.org/the-status-of-nepals-birds-the-national-red-list-seri es-2016/

[36] Grimmett, R., Inskipp, C. and Inskipp, T. (2016) Birds of the Indian Subcontinent. 2nd Edition, Printed and bound in India by Replika Press Pvt. Ltd., Oxford University Press, Oxford.

[37] Shrestha, T.K. (2000) Birds of Nepal. Field Ecology, Natural History and Conservation. Published by Mrs. Bimala Shrestha. R. K. Printers, Teku, Kathmandu, Nepal. Vol. I.

[38] Shrestha, T.K. (2001) Birds of Nepal. Field Ecology, Natural History and Conservation. Published by Mrs. Bimala Shrestha. R. K. Printers, Teku, Kathmandu, Nepal. Mrs. Bimala Shrestha, Nepal, Vol. II.

[39] Baral, H.S. (2003) Helm Field Guides "Nepal Ka Charaharu”, Translated Book in Nepali by H.S. Baral in 2003 from the Book "Birds of Nepal” Written by Grimmett, R., Inskipp, C., Inskipp, T. and Baral, H.S. Published by Christopher Helm Ltd., 2003.

[40] Jnawali, S.R., et al. (2011) The Status of Nepal's Mammals: The National Red List Series, Department of National Parks and Wildlife Conservation Kathmandu, Nepal. https://awsassets.panda.org/downloads/nepal redlist low $09 \quad 06 \quad 2012$ 1.pdf

[41] Nowak, R.M. and Paradiso, J.L. (1983) Walker's Mammals of the World, 4th Edition. Vol. II, The Johns Hopkins University Press, Baltimore and London, 937-949.

[42] Shrestha, T.K. (1997) Mammals of Nepal with Reference to Those of India, Bangaladesh, Bhutan and Pakistan. R. K. Printers, Teku, Kathmandu, Nepal, 95-97, 126-129.

[43] Menon, V. (2014) Indian Mammals: A Field Guide. Hachette Book Publishing India Pvt. Ltd., Gurgaon, India.

[44] Baral, H.S. and Shah, K.B. (2008) Wild Mammals of Nepal. Himalayan Nature, Kathmandu, 104-109.

[45] Wang, W., et al. (2016) The Evidence of Clade 7.1 Avian Influenza Virus (H5N1) in 
Qinghai Lake. Advances in Microbiology, 6, 1053-1061. https://doi.org/10.4236/aim.2016.614098

[46] Chaudhary, B. and Pandey, D.P. (2019) Snapshot View of Intestinal Parasites in Wild Birds of Chitwan District, the Southcentral Lowlands of Nepal. Journal of Parasitology Research, 15, 1-8. https://doi.org/10.3923/jp.2020.1.8

[47] Araujo Carreira, J.C., Bueno, C. and Machado da Silva, A.V. (2020) Wild Mammal Translocations: A Public Health Concern. Open Journal of Animal Sciences, 10, 64-133. https://doi.org/10.4236/ojas.2020.101006

[48] CNP. (2006) Chitwan National Park. https://en.wikipedia.org/wiki/Chitwan_National_Park

[49] St. Pierre, J.I. and Kovalenko, K.E. (2014) Effect of Habitat Complexity Attributes on Species Richness. Ecosphere, 5, 1-10. https://doi.org/10.1890/ES13-00323.1

[50] Dickman, C.R. and Doncaster, C.P. (1989) The Ecology of Small Mammals in Urban Habitats. II. Demography and Dispersal. Journal of Animal Ecology, 58, 119-127. http://www.jstor.org/stable/4989

[51] Jahnig, S., et al. (2020) Microclimate Affects the Distribution of Grassland Birds, but Not Forest Birds, in an Alpine Environment. Journal of Ornithology, 161, 677-689. https://doi.org/10.1007/s10336-020-01778-5

[52] Loveridge, A.J. and Macdonald, D.W. (2002) Habitat Ecology of Two Sympatric Species of Jackals in Zimbabwe. Journal of Mammalogy, 83, 599-607.

https://doi.org/10.1644/1545-1542(2002)083<0599:HEOTSS>2.0.CO;2

[53] Lanszki, J., Heltai, M. and zabó, L.S. (2006) Feeding Habits and Trophic Niche Overlap between Sympatric Golden Jackal (Canis aureus) and Red Fox (Vulpes vulpes) in the Pannonian Ecoregion (Hungary). Canadian Journal of Zoology, 84, 1647-1656. http://real.mtak.hu/7108/

[54] Weisser, W.W., et al. (2017) Biodiversity Effects on Ecosystem Functioning in a 15-Year Grassland Experiment: Patterns, Mechanisms, and Open Questions. Basic and Applied Ecology, 23, 1-73. https://doi.org/10.1016/j.baae.2017.06.002

[55] Tanis (Marco), M.F., Marshall, L., Biesmeijer (Koos), J.C. and Van Kolfschoten, L. (2020) Grassland Management for Meadow Birds in the Netherlands is Unfavourable to Pollinators. Basic and Applied Ecology, 43, 52-63. https://doi.org/10.1016/j.baae.2019.12.002

[56] Muchhala, N. (2003) Exploring the Boundary between Pollination Syndromes: Bats and Hummingbirds as Pollinators of Burmeistera cyclostigmata and B. tenuiflora (Campanulaceae). Oecologia, 134, 373-380. https://doi.org/10.1007/s00442-002-1132-0

[57] Klein, A.-M., et al. (2007). Importance of Pollinators in Changing Landscapes for World Crops. Proceedings of the Royal Society B: Biological Sciences, 274, 303-313. https://doi.org/10.1098/rspb.2006.3721

[58] Stiles, F.G. (1978) Ecological and Evolutionary Implications of Bird Pollination. American Zoologist, 18, 715-727. https://doi.org/10.1093/icb/18.4.715

[59] Pinotti, B.T., Naxara, L. and Pardini, R. (2011) Diet and Food Selection by Small Mammals in an Old-growth Atlantic Forest of South-Eastern Brazil. Studies on Neotropical Fauna and Environment, 46, 1-9. https://doi.org/10.1080/01650521.2010.535250

[60] Katuwal, H.B. and Dahal, S. (2013) Golden Jackals in Human Dominated Landscapes of the Manaslu Conservation area, Nepal. Vertebrate Zoology, 63, 329-334. https://www.researchgate.net/publication/278787855 